\title{
The Sanriku-oki, Japan, earthquake of December 28, 1994 (Mw 7.7): Rupture of a different asperity from a previous earthquake
}

\author{
Yuichiro Tanioka, Larry Ruff \\ Dept. of Geological Science, University of Michigan, Ann Arbor
}

\author{
Kenji Satake \\ Seismotectonics Section, Geological Survey of Japan, Tsukuba
}

\begin{abstract}
Fault geometry, depth, and slip distribution of the Sanriku-oki earthquake of December 28, 1994 (Ms 7.5) are estimated from seismic waveforms, geodetic measurements, and tsunami waveforms, and compared with those of the 1968 Tokachi-oki earthquake (Mw 8.2), the most recent large earthquake in the epicentral region. Seismic wave inversions indicate a shallowly dipping thrust type mechanism and the focal depth of 22-28 km, representing an underthrust event at the subduction interface. The source time function has an initial stage of $20 \mathrm{~s}$ followed by a main pulse of $30 \mathrm{~s}$ duration, a shape similar to that of the 1968 Tokachi-oki earthquake. Joint inversion of geodetic and tsunami data shows that the region of the largest slip, $1.7 \mathrm{~m}$, corresponds to a region of relatively small slip for the 1968 Tokachi-oki earthquake. Furthermore, the joint inversion shows that the region of the largest asperity of the 1968 earthquake had essentially zero slip during the 1994 Sanriku-oki earthquake. These results indicate that the dominant asperities ruptured by the 1994 Sanriku and 1968 Tokachi-oki earthquakes are different. The result of the joint inversion also shows that the aseismic zone near the Japan trench was not ruptured by the 1994 earthquake.
\end{abstract}

\section{Introduction}

A large earthquake occurred off the Sanriku, Honshu, coast along the Japan trench on December 28, 1994. The NEIS Preliminary Determination of Epicenters (PDE) provides the source parameters: origin time, 12:19:23.0 GMT; epicenter, $40.525^{\circ} \mathrm{N}, 143.419^{\circ} \mathrm{E}$; depth, $27 \mathrm{~km}$; and magnitude, Ms 7.5. This earthquake caused significant damage including three fatalities in the Hachinohe area, Japan. The earthquake generated a tsunami which was recorded at tide gauge stations along the Pacific coast in northern Japan.

Many large earthquakes have occurred due to the subduction of the Pacific plate along the Japan trench. The most recent one in the 1994 epicentral region was the 1968 Tokachi-oki earthquake (Mw 8.2) (Figure 1), which has been extensively studied by using seismic waves [Kikuchi and Fukao, 1985; Mori and Shimazaki, 1985; Schwartz and Ruff, 1985] and tsunami waveforms [Satake, 1989]. All these results suggest that little slip occurred in the southernmost part of the aftershock area. The 1994 event occurred in the southern part of the 1968 aftershock area. The epicenters of the two earthquakes are also very close, less than $30 \mathrm{~km}$ apart. The seismicity of this region has been also studied by using ocean bottom seismometers (OBS) [Hirata et

\section{Copyright 1996 by the American Geophysical Union.}

Paper number 96GL01132

0094-8534/96/96GL-01 132\$05.00 al., 1985; Nishizawa et al., 1992; Suyehiro and Nishizawa, 1994]. The results suggest that a $50-\mathrm{km}$-wide aseismic zone exists along the Japan trench. Byrne et al. [1988] suggest that the primary cause for this type of aseismic zone is the stable slip properties of the unconsolidated or semiconsolidated sediments in that zone.

The purpose of this paper is to answer two key questions: did the 1994 Sanriku-oki event rerupture the largest asperity of the 1968 Tokachi-oki earthquake? Did the 1994 event rupture the aseismic zone near the Japan trench? In order to do so, we determine the source process of the 1994 Sanriku-oki earthquake from seismic, tsunami, and geodetic data.

\section{Seismological Analysis}

\section{Data and Method}

We performed the Centroid Moment Tensor (CMT) inversion [Dziewonski et al., 1981; Fukushima et al., 1989] using longperiod surface waves recorded at 18 IRIS stations (AFI, ANMO,

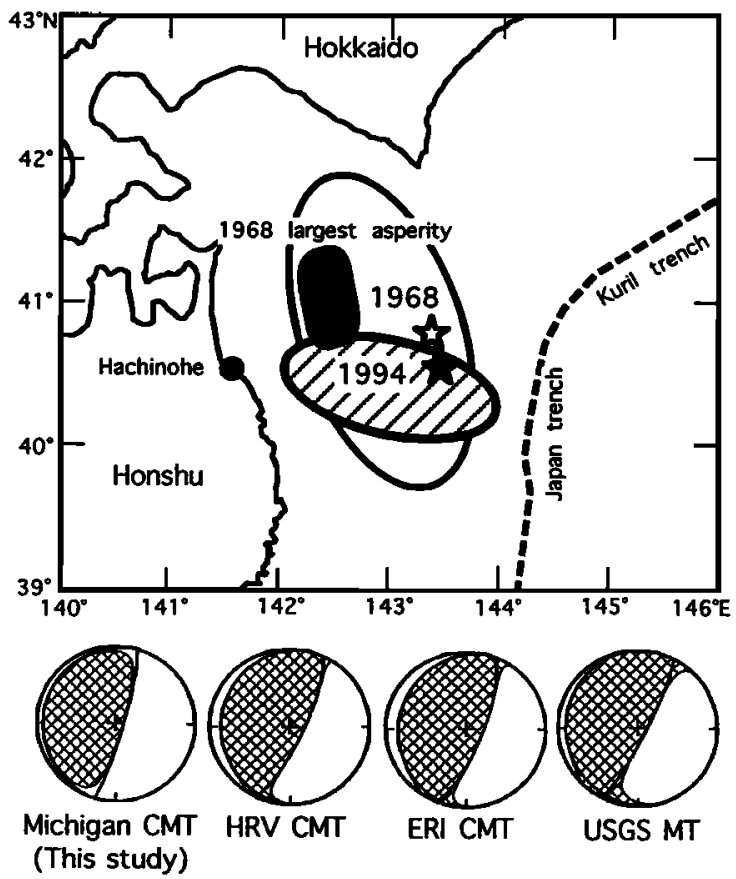

Figure 1. (top) The aftershock area of the 1994 Sanriku-oki earthquake (shaded ellipsoid) and the 1968 Tokachi-oki earthquake (open ellipsoid). Open star and solid star are the epicenters of the 1968 and 1994 earthquakes, respectively. The largest asperity of the 1968 event is schematically shown. (bottom) Four different solutions of the focal mechanism of the 1465 
ANTO, BGIO, CMB, COR, ESK, FFC, HRV, KEV, KONO, NWAO, PAB, PAS, PMG, RAR, SNZO, and TATO) to estimate the overall focal mechanism and seismic moment. We also performed the Moment Tensor Rate Function (MTRF) inversion [Ruff and Miller, 1994] using $15 \mathrm{P}$ waves (AFI, ANMO, CCM, CMB, COL, COR, CTAO, ESK, FFC, HNR, HRV, KONO, PAS, PMG, and TUC) and 1 SH wave (COL) recorded at IRIS stations. We performed this to estimate the focal mechanism and the best depth of the earthquake. We then reinverted the seismograms at the above best depth and focal mechanism to estimate the source time function. The average $P$ and $S$ wave velocities from the ground surface to the hypocenter are assumed to be crustal values of $6.7 \mathrm{~km} / \mathrm{s}$ and $3.9 \mathrm{~km} / \mathrm{s}$, respectively. The details of the analysis will be discussed below. We compare these estimates with those from Harvard CMT, Earthquake Research Institute (ERI) CMT, U.S. Geological Survey (USGS) moment tensor inversions. Comparison of focal mechanisms determined in the different frequency bands is used to check the complexity of earthquake source process [e.g. Tanioka et al., 1995b].

\section{Focal Mechanism and Depth}

The focal mechanism of the 1994 Sanriku-oki event from our CMT inversion has a nodal plane dipping shallowly to the west (strike $=180^{\circ}$, dip $=9^{\circ}$, rake $=75^{\circ}$ ) as shown in Figure 1 . The focal mechanisms from the Harvard, ERI, and USGS moment tensor inversions, also shown in Figure 1, and from our MTRF inversion, shown in Figure 2, indicate basically the same geometry. All of these five different determinations indicate a shallow thrust-type fault motion, representing a plate interface event. The consistency among these five estimates over a wide frequency range suggests that the focal mechanism did not vary during the entire rupture process.

The best depth from the MTRF inversion is $22 \mathrm{~km}$ (Figure 2). The USGS depth is $7 \mathrm{~km}$. The centroid depth by Harvard and ERI is 27.7 and $22.2 \mathrm{~km}$, respectively. Except for the USGS estimate, there appears to be a fairly good agreement that the best overall depth lies between 22 and $28 \mathrm{~km}$. Suyehiro and Nishizawa [1994] found from the OBS observations that the upper depth of the seismic coupling zone is about $15 \mathrm{~km}$. Tichelaar and Ruff [1993] found that the maximum depth of the seismic coupling zone in northern Honshu is $37-43 \mathrm{~km}$. If this entire width of the plate interface ruptures uniformly, the average depth for such an earthquake would be $26-29 \mathrm{~km}$. This is

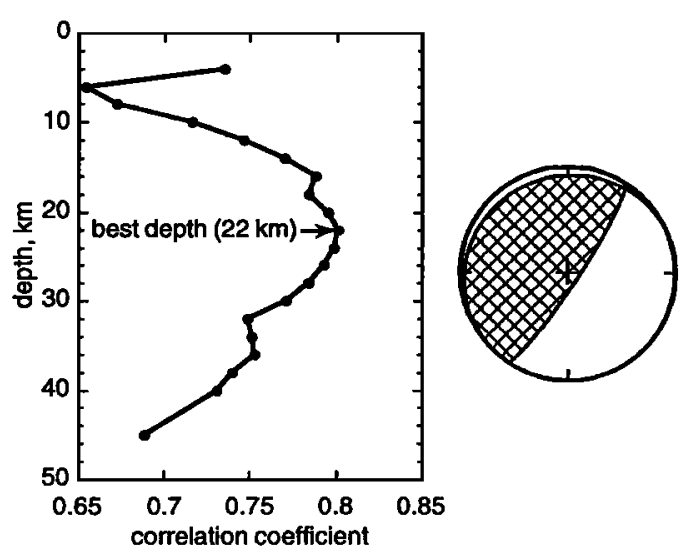

Figure 2. (Left) The correlation coefficient between the observed and synthetic body waves as a function of depth. (Right) The best double couple focal mechanism as a result of the MRTF inversion.
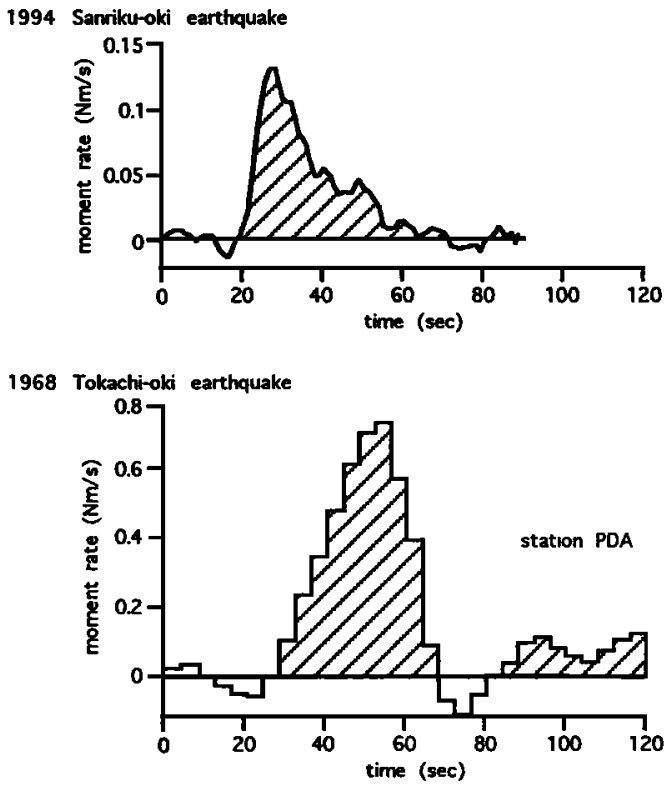

Figure 3. Comparison of the source time functions for the 1994 Sanriku-oki earthquake (from this study) and the 1968 Tokachioki earthquake (from Schwartz and Ruff [1985])

consistent with the best overall depth estimate of the 1994 Sanriku-oki event.

\section{Source Time Function}

The source time function of the 1994 earthquake estimated from body wave inversion is shown in Figure 3. The source time history consists of two stages: the initiation stage (duration $20 \mathrm{~s}$ ) and the main pulse (duration $36 \mathrm{~s}$ and seismic moment of $2.3 \mathrm{x}$ $10^{20} \mathrm{Nm}$ ). The long initiation stage is also observed in the source time history of the 1968 Tokachi-oki earthquake with a duration of about $30 \mathrm{~s}$ [Kikuchi and Fukao, 1985; Schwartz and Ruff, 1985] (Figure 3). The general shape of the 1994 source time function is similar to that of the 1968 Tokachi-oki event. However, in detail, the 1994 event took only $9 \mathrm{~s}$ from the onset of the main pulse to reach the maximum moment rate. The 1968 event reaches the maximum in about $30 \mathrm{~s}$ after the main pulse initiation. This difference should be related to the difference in the slip distribution of the two earthquakes. We then performed the joint inversion of tsunami and geodetic data [Satake, 1993] to estimate the slip distribution of the 1994 Sanriku-oki earthquake as shown below.

\section{Tsunami and Geodetic Analysis}

\section{Data and Method}

For the joint inversion, we used the tsunami waveforms recorded at 8 tide gauge stations, 4 in Hokkaido and 4 in Honshu. The tsunami waveform for each tide gauge station consists of 30 70 min of data with a sampling interval of $1 \mathrm{~min}$. We also used the horizontal coseismic displacements observed at 10 GPS stations (Figure 4) operated by the Geographical Survey Institute of Japan [Tsuji et al., 1995]. The tsunami Green's functions are numerically computed on actual bathymetry. Finite difference computations of the linear long wave equations are carried out with a grid size of 1 minute of the arc [Satake, 1995]. The initial condition of tsunami propagation is calculated from the vertical and horizontal displacements of the ocean bottom [Tanioka and 


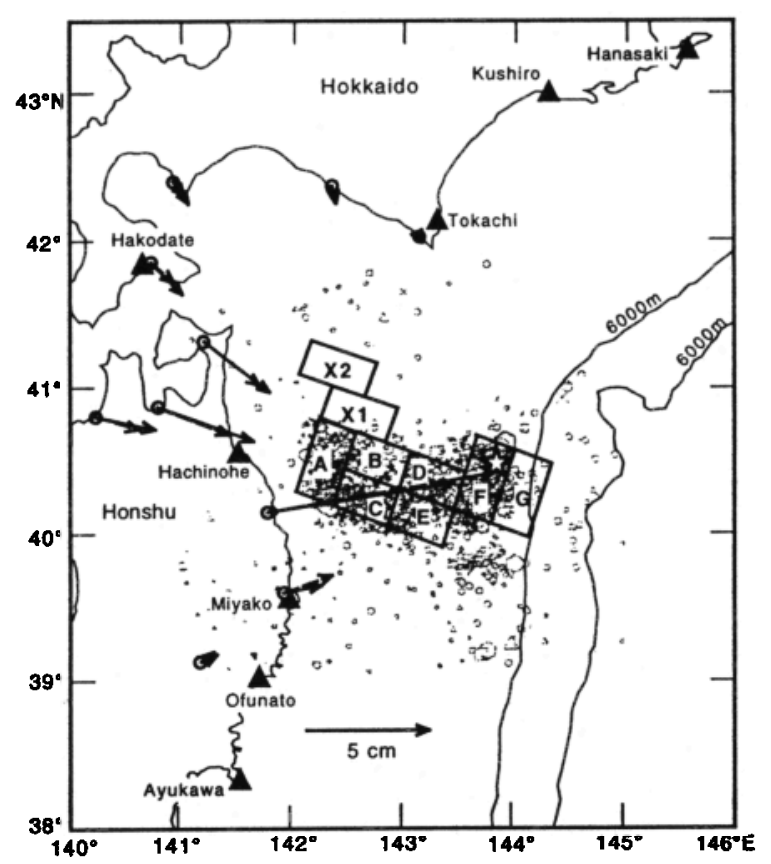

Figure 4. Fault model and fit to geodetic data. Frames show the location of nine subfaults. Results of the joint inversion for slip distribution are in Table 1. Solid and dashed arrows are the observed horizontal displacements [Tsuji et al., 1995] and computed displacements, respectively. A star and gray symbols show the epicenter and aftershocks of the 1994 Sanriku-oki earthquake determined by Matsuzawa et al. [1995]. Triangles show the tide gauge stations used in this study.

Satake, 1996]. The coseismic displacement is computed using Okada's [1985] equations. For error analysis, we applied the jackknifing technique [e.g. Tichelaar and Ruff, 1989].

\section{Slip Distribution}

We assumed a pure thrust-type fault (strike $=200^{\circ}, \operatorname{dip}=10^{\circ}$, rake $=90^{\circ}$ ) for the joint inversion of tsunami and geodetic data. We divided the aftershock area [Matsuzawa et al., 1995] into seven (A-G) subfaults as shown in Figure 4. The length and

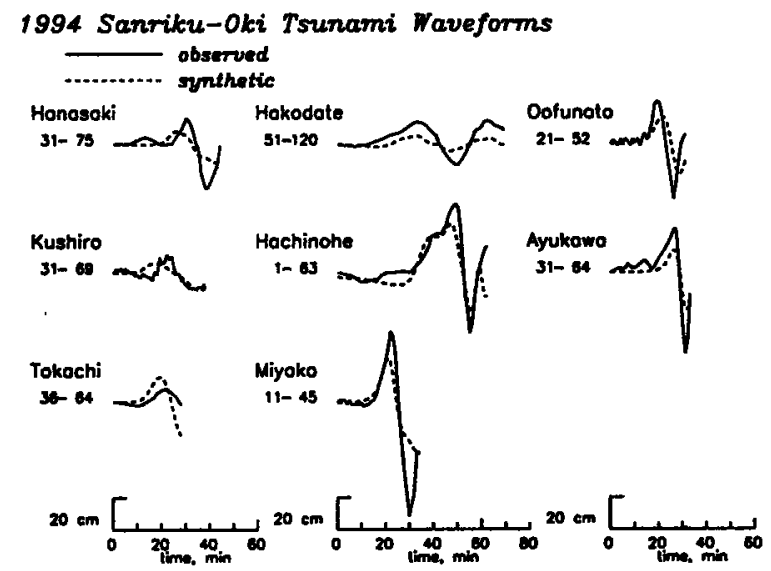

Figure 5. Comparison of the observed (solid) and computed (dashed) tsunami waveforms from the joint inversion for the nine subfaults in Figure 4. The numbers below the station name indicate the time range of the waveforms (in min after the origin time).
Table 1 Slip distribution with nine subfaults

\begin{tabular}{cccc}
\hline subfault & slip, m & subfault & slip,m \\
\hline A & $0.75 \pm 0.04$ & F & $0.56 \pm 0.06$ \\
B & $0.65 \pm 0.33$ & G & $-0.01 \pm 0.12$ \\
C & $0.93 \pm 0.43$ & X1 & $-0.04 \pm 0.13$ \\
D & $0.73 \pm 0.08$ & X2 & $0.03 \pm 0.07$ \\
E & $1.71 \pm 0.12$ & &
\end{tabular}

Note: see Figure 4 for the subfault location.

width of subfaults $A, F$, and $G$ are $60 \mathrm{~km}$ and $30 \mathrm{~km}$, respectively. The length and width of subfaults $B, C, D$, and $E$ are $30 \mathrm{~km}$ and $45 \mathrm{~km}$, respectively. The centroid depth for each subfault is assumed to be $38 \mathrm{~km}$ for subfault $A, 31 \mathrm{~km}$ for subfaults $B$ and C, $23 \mathrm{~km}$ for subfaults $D$ and $E, 16 \mathrm{~km}$ for subfault $F$, and $10 \mathrm{~km}$ for subfault $G$. Furthermore, we add two more subfaults (X1 and X2) outside the 1994 aftershock area; those two cover the largest asperity of the 1968 Tokachi-oki event [Satake, 1989]. The length and width of the two additional subfaults are $30 \mathrm{~km}$ and $60 \mathrm{~km}$, respectively. The result of the joint inversion is shown in Table 1 . The observed and computed horizontal displacements (Figure 4) show a good agreement. The computed tsunami waveforms (Figure 5) also agree with the observations.

The largest slip, $1.7 \mathrm{~m}$, found on subfault $\mathrm{E}$, is almost twice as large as the second largest slip, $0.9 \mathrm{~m}$, on subfault $\mathrm{C}$. The best depth determined from the MTRF inversion, $22 \mathrm{~km}$, lies on subfault $E$. There is essentially no slip on the two subfaults outside the aftershock area, X1 and X2. This indicates that the largest asperity ruptured by the 1968 Tokachi-oki earthquake did not rupture in the 1994 Sanriku earthquake. The slip on the shallowest subfault located near the trench, subfault G, is also practically zero, which indicates that the aseismic zone near the Japan trench was not ruptured by the 1994 Sanriku-oki earthquake.

The total seismic moment from all the subfaults is computed as $3.1 \times 10^{20} \mathrm{Nm}(\mathrm{Mw}=7.6)$, assuming that the rigidity is $4 \times 10^{10}$ $\mathrm{N} / \mathrm{m}^{2}$. This is slightly smaller than our CMT estimate of $4.5 \mathrm{x}$ $10^{20} \mathrm{Nm}(\mathrm{Mw}=7.7)$, the Harvard estimate of $4.9 \times 10^{20} \mathrm{Nm}$, and the USGS estimate of $4.0 \times 10^{20} \mathrm{Nm}$. It is somewhat larger than the MTRF estimate of $2.3 \times 10^{20} \mathrm{Nm}$ and the ERI estimate of 2.2 $x 10^{20} \mathrm{Nm}$. This scatter in the seismic moment estimates is "typical", and possibly due to the different frequency band of data or the different centroid depth.

The average error for the slip estimate is $15 \mathrm{~cm}$. Satake [1989] determined the slip distribution of the 1968 Tokachi-oki

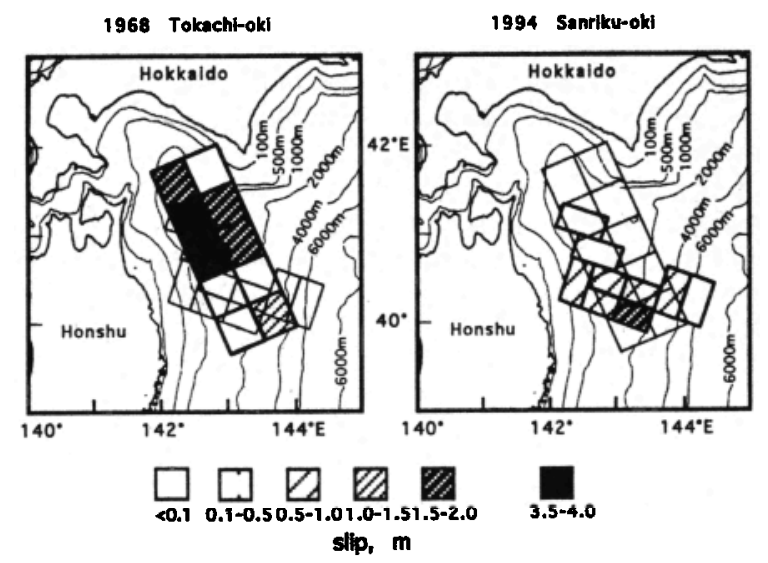

Figure 6. Comparison of the slip distributions for the 1994 Sanriku-oki and 1968 Tokachi-oki earthquakes. 
earthquake from the inversion of tsunami waveforms with an average error of $47 \mathrm{~cm}$. The spatial resolution also seems better for the 1994 Sanriku event, because we used the geodetic data as well as tsunami waveforms to estimate the slip distribution. Hence we could estimate the slip distribution for the 1994 Sanriku-oki earthquake using smaller subfaults.

\section{Discussion and Conclusion}

Sato et al. [1996] and Hartog and Schwartz [1995] suggest a westward rupture propagation for the 1994 Sanriku earthquake. If it propagated from the epicenter (subfault F) toward the west (subfault A) with a standard rupture velocity of $3 \mathrm{~km} / \mathrm{s}$, the source time function determined by the MTRF inversion and the slip distribution determined from the joint inversion are wellcorrelated. The peak moment release occurred in the region of subfaults $D$ and $E$.

We compare in Figure 6 the slip distribution of the 1994 Sanriku-oki earthquake with that of the 1968 Tokachi-oki earthquake determined by Satake [1989]. The region of the largest slip for the 1994 Sanriku-oki earthquake corresponds to a region of relatively small slip for the 1968 Tokachi-oki earthquake. The region of the largest slip for the 1968 Tokachioki earthquake did not slip in the 1994 Sanriku-oki earthquake. These results indicate that the dominant asperities ruptured by the 1994 Sanriku and 1968 Tokachi-oki earthquakes are different, although the rupture areas overlap.

We found that the 1994 Sanriku-oki earthquake did not rupture the aseismic zone near the Japan trench. However, Tanioka et al., [1995a] suggest that the 1896 Sanriku tsunami earthquake might have ruptured the aseismic zone near the Japan trench. Future studies are necessary to understand the nature of the aseismic zone at the up-dip side of the seismic coupling zone.

Acknowledgments. We thank J. Johnson and N. Winslow for helpful comments. The tide gauge records in Japan were provided to us by $\mathrm{Y}$. Tsuji and K. Arai. This work was supported by NSF (EAR 9405767).

\section{References}

Byrne, D.E., D.M. Davis, and L.R. Sykes, Loci and maximum size of thrust earthquakes and the mechanics of the shallow region of subduction zone, Tectonics, 7, 833-857, 1988.

Dziewonski, A.M., T.A. Chou, and J.H. Woodhouse, Determination of earthquake source parameters from waveform data for studies of global and regional seismicity, J. Geophys. Res.,86, 2825-2853, 1981.

Fukushima, T., D. Suetsugu, I.Nakanishi, and I. Yamada, Moment tensor inversion for near earthquakes using long-period digital seismographs, J. Phys. Earth, 37,1-29, 1989.

Hartog, R., and S. Schwartz, Directivity analysis of the December 28, 1994 (Mw=7.7) earthquake off the coast of Honshu, Japan, Abstracts of the 1995 IUGG XXI General Assembly, B, 331, 1995.

Hirata, N., K. Kanazawa, K. Suyehiro, and H. Shimamura, A seismicity gap beneath the inner wall of the Japan trench as derived by OBS measurement, Tectonophysics, 112, 193-209, 1985.

Kikuchi, M., and Y. Fukao, Iterative deconvolution of complex body waves from great earthquakes - the Tokachi-Oki earthquake of 1968, Phys. Earth Planet. Inter., 37, 235-248, 1985.
Matsuzawa, T., Umino, N., Horiuchi, S.,Hasegawa, A., and Hirasawa, T., Aftershock activity of the 1994 far east off Sanriku earthquake observed by a microearthquake observation network, Abstracts of the 1995 Japan Earth and Planetary Sciences Joint Meeting, 36, 1995 (in Japanese)

Mori, J., and K. Shimazaki, Inversion of intermediate-period Rayleigh waves for source characteristics of the 1968 Tokachi-oki earthquake, J. Geophys. Res., 90,11374-11382, 1985.

Nishizawa, A., T. Kanazawa, T. Iwasaki, H. Shimamura, and N. Hirata, Spatial distribution of earthquakes associated with the Pacific plate subduction off northeastern Japan revealed by the ocean bottom and land observation, Phys. Earth Planet. Inter., 75, 165-173, 1992.

Okada, Y., Surface deformation due to shear and tensile faults in a halfspace, Bull. Seism. Soc. Am.,75, 1135-1154, 1985.

Ruff, L.J., and A.D. Miller, Rupture process of large earthquakes in the northern Mexico subduction zone, Pure Appl. Geophys., 142, 101-172, 1994.

Satake, K., Inversion of tsunami waveforms for the estimation of heterogeneous fault motion of large submarine earthquakes: the 1968 Tokachi-oki and the 1983 Japan Sea earthquakes, J. Geophys. Res., 94, 5627-5636, 1989.

Satake, K., Depth distribution of coseismic slip along the Nankai Trough, Japan, from joint inversion of geodetic and tsunami data, J. Geophys. Res., 98, 4553-4565,1993.

Satake, K., Linear and nonlinear computations of the 1992 Nicaragua earthquake tsunami, Pure Appl. Geophys., 144, 455-470, 1995.

Sato, T., K. Imanishi, and M. Kosuga, Three-stage rupture process of the 28 December 1994 Sanriku-oki earthquake, Geophys. Res. Lett., 23, 33-36, 1996.

Schwartz, S.Y., and L.J. Ruff, The 1968 Tokachi-Oki and the 1969 Kurile Islands earthquakes: Variability in the rupture process, J.Geophys. Res., 90, 8613-8626, 1985.

Suyehiro, K., and A. Nishizawa, Crustal structure and seismicity beneath the forearc off northeastern Japan, J. Geophys. Res., 99, 22331-22347, 1994.

Tanioka, Y., J.M. Johnson, and K. Satake, Mechanism of tsunami earthquakes, EOS, Trans. AGU, 76, F382, 1995a.

Tanioka, Y., K. Satake, and L.J. Ruff, Total analysis of the 1993 Hokkaido Nansei-oki earthquake using seismic wave, tsunami, and geodetic data, Geophys. Res. Lett., 22, 9-12, 1995b.

Tanioka, Y., and K. Satake, Tsunami generation by horizontal displacement of ocean bottom, Geophys. Res. Lett., in press, 1996.

Tichelaar, B.W., and L.J. Ruff, How good are our best models? Jackknifing, bootstrapping, and earthquake depth, EOS, Trans. Am. Geophys. Union 70, 593,605-606, 1989.

Tichelaar, B.W., and L.J. Ruff, Depth of seismic coupling along subduction zones, J. Geophys. Res., 98, 2017-2037, 1993.

Tsuji, H., Y. limura, K. Kobayashi, H. Morishita, and Y. Hatanaka, Results from GSI's nationwide array during her maiden voyage, Abstracts of the 1995 Japan Earth and Planetary Sciences Joint Meeting, 522,1995 (in Japanese).

K. Satake, Seismotectonics Section, Geological Survey of Japan, Tsukuba, Ibaraki 305, Japan (e-mail: satake@gsj.go.jp)

L. Ruff, Y. Tanioka, Dept. of Geological Sciences, Univ. of Michigan, Ann Arbor, MI 48109-1063. (e-mail: ruff@umich.edu, tanioka@umich.edu)

(Received December 6, 1995; revised February 19, 1996; accepted March 22, 1996.) 